\title{
Analisa Koordinasi Over Current Relay Pada Pabrik Cement Mill Indarung III PT. Semen Padang
}

\author{
Zulkarnaini $^{1}$, Sepriadi ${ }^{2}$ \\ Dosen ${ }^{1}$, Mahasiswa ${ }^{2}$ Teknik Elektro, Fakultas Teknologi Industri, Institut Teknologi \\ Padang \\ E-mail: zulkarninieva@gmail.com ${ }^{I}$ \\ DOI: http://dx.doi.org/10.31869/rtj.v4i1.1950
}

\begin{abstract}
Abstrak: Sistem proteksi mempunyai peran penting untuk mencegah kerusakan lebih parah akibat adanya gangguan dalam sebuah sistem tenaga. Sehingga jaringan sistem tenaga bisa bekerja sesuai dengan performa yang diharapkan. Analisa dan pengecekan keandalan koordinasi rele proteksi bertujuan untuk menjaga dan meningkatkan performa kerja rele proteksi. Sebelum pensimulasian dilakukanlah perhitungan secara manual untuk mendapatkan nilai arus setting over current relay, arus pick-up, time dial, serta karateristik instantanius over current relay. Kemudian hasil perhitungan itu dijadikan sebagai input pada software ETAP 12.6. Hasil running simulasi protective device coordination dan hasil analisa pada enam (6) kali skenario gangguan yang dilakukan diperoleh, bahwa sistem proteksi pada jaringan distribusi pabrik Pabrik Cement Mill Indarung III PT. Semen Padang masih bekerja dengan baik. Dari 6 kali scenario gangguan yang dilakukan, terdapat koordinasi rele OCR yang baik dan kurang baik yang terbawah .Koordinasi terbaik adalah koordinas rele OCR pada scenario keenam yaitu gangguan pada bus MDB 4.2. Rele OCR yang dikoordinasikan adalah rele trafo 4.2 dengan rele Incoming Z1, dimana perbedan nilai Time Dial-nya adalah 0.09 dengan perbedaan waktu trip CB rele trafo 4.2 dengan CB rele incoming Z1 adalah 25 ms. Sedangkan urutan koordinasi terbawah adalah koordinasi pada scenario pertama yaitu gangguan pada bus MDB PG. Rele OCR yang dikoordinasikan adalah rele trafo 2 dengan rele incoming PG, dimana perbedaan nilai Time Dialnya adalah 0.51 dengan perbedaan waktu trip CB rele trafo 2 dengan CB incoming PG adalah $870 \mathrm{~ms}$.
\end{abstract}

Kata kunci: Proteksi, OCR, Setting,

\section{PENDAHULUAN}

Dalam pengoperasian operasi produksi pada pabrik ini, sistem tenaga listrik dapat mengalami berbagai macam gangguan, misal gangguan dari hubung singkat yang akan mengakibatkan terhentinya penyaluran energi listrik yang akhirnya akan membuat proses produksi terkendala. Akibat lain dari gangguan tersebut adalah dapat merusak peralatanperalatan produksi yang

terhubung dalam sistem tenaga listrik dan dapat juga meluas ke sistem yang lain. Tugas dasar sistem proteksi adalah untuk memonitor komponen pada sistem yang mengalami gangguan dan dimungkinkan hanya untuk memutuskan komponen tersebut agar pendistribusian energi listrik tetap terjaga ke system yang lain. Untuk itu sistem proteksi harus bekerja secara cepat dan selektif dalam mengamankan peralatan-peralatan listrik yang sedang mengalami gangguan-gangguan arus lebih dan arus hubung singkat fasa ke fasa dengan pemasangan rele arus lebih (Over
Current Relay) pada masing-masing feeder di PT. Semen Padang. Berdasarkan hasil simulasi akan dapat dilihat seberapa efektif program ETAP untuk melihat koordinasi kerja rele arus lebih dan apabila terjadi gangguan pada Cement Mill Indarung III PT. Semen Padang.[1]

\section{Sistem Tenaga Listrik}

Sistem tenaga listrik adalah suatu sistem yang terdiri dari beberapa komponen berupa pembangkitan, transmisi, distribusi dan beban yang saling berhubungan dan berkerja sama untuk melayani kebutuhan tenaga listrik bagi pelanggan sesuai kebutuhan. Secara garis besar Sistem Tenaga Listrik dapat digambarkan sebagai berikut.[2]

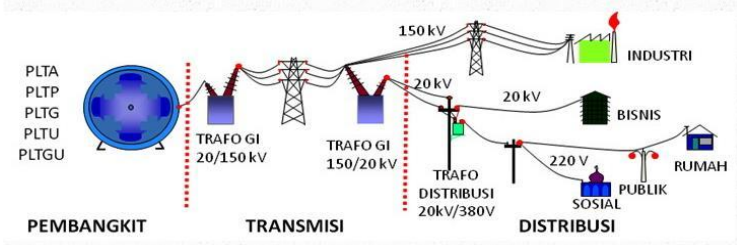

Gbr 1. Sistem Tenaga Listrik.[3] 


\section{Gangguan Pada Sistim Tenaga.}

1. Gangguan Beban Lebih.

Sebenarnya bukan gangguan murni, tetapi jika dibiarkan terus-menerus maka dapat merusak peralatan. Umumnya gangguan beban lebih yang terjadi pada transformator yang memiliki kemampuan atau daya tahan terhadap $110 \%$ pembebanan secara berulang, meskipun demikian kondisi tersebut sudah merupakan keadaan beban lebih yang diamankan. Dengan mengetahui kemampuan pembebanan tersebut penyetelan rele beban lebih baik dikoordinasikan dengan pengamanan gangguan hubung singkat. 2. Gangguan Hubung Singkat ( Short Circuit ) Gangguan hubung singkat dapat terjadi 3 fasa, 2 fasa dan satu fasa ke tanah. Gangguan yang terjadi dapat bersifat temporer atau permanen[4]

\subsection{Rele Arus Lebih (Over Current Relay)}

Over Current Rela (OCR) Adalah suatu rangkaian peralatan rele pengaman yang memberikan respon terhadap kenaikan arus yang melebihi arus yang telah ditentukan pada rangkaian yang diamankan.

1. Rele Arus Lebih Sesaat/Momen Prinsip kerja rele ini adalah tanpa penundaan waktu, tapi bekerja dengan waktu cepat sebesar 0,1 detik. Pada umumnya kurang dari 0,08 detik [5].

2. Rele Arus Lebih Dengan Waktu Tunda

Bekerjanya relay berdasarkan pada waktu tunda (settingan) dengan tidak melihat besarnya arus gangguan.

3 Rele Arus Lebih Waktu Terbalik Karakteristik grafiknya terbalik antara arus dan waktu, dimana semakin besar arus gangguan hubung singkat maka semakin kecil waktu yang dibutuhkan untuk membuka pemutus (CB) sehingga dalam settingnya rele perlu mengetahui besarnya arus hubung singkat untuk tiap seksi. [7]

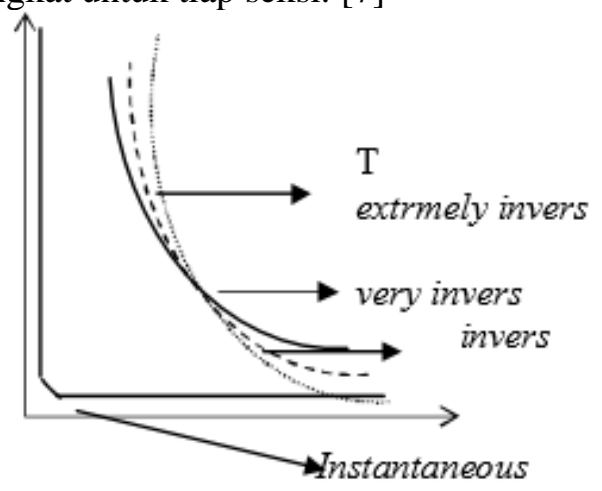

Gbr 2. Karakteristik OCR Inverse Perhitungan setting rele
$>$ Arus nominal In=Ibase (arus kerja peralatan listrik dalam keadaan normal)

$\square$ Arus kerja rele (standar OCR 110\%) Iset $=$ In $\mathrm{x} 1.1 \quad$ Dimana $\mathrm{In}=$ arus nominal[6]

$>$ Pic-up

$$
\text { pick }-u p=\frac{I_{s e t}}{C T_{p}}
$$

Dimana $\mathrm{CTp}=$ ratio trafo arus pada sisi primer[1]

\section{$>$ Time Dial}

$$
\begin{aligned}
t_{o p} & =\frac{\beta x t_{d}}{k\left(\frac{I_{\text {faut }}}{I_{\text {set }}}\right)^{\alpha}-1} \\
t_{d} & =\frac{t_{o p} \times k\left[\left(\frac{I_{\text {faut }}}{I_{\text {set }}}\right)^{\alpha}-1\right] \ldots \ldots . . .}{\beta}
\end{aligned}
$$

Dimana :

$$
\begin{array}{ll}
t_{d} & =\text { Time Dial } \\
t_{\text {op }} & =\text { Waktu Operasi } \\
I_{\text {fault }} & =\text { Arus gangguan maksimal } \\
I_{\text {set }} & =\text { Arus Setting } \\
\alpha & =\text { konstanta } \\
\beta & =\text { konstanta } \\
k & =\text { konstanta }
\end{array}
$$

Tabel 1 Karakteristik OCR IEC 60255

\begin{tabular}{|c|c|c|c|}
\hline Jenis kurva IEC & & & $\mathbf{k}$ \\
\hline IEC Standard Inverse & 0,02 & 0,14 & 2,970 \\
\hline IEC Very Inverse & 1 & 13,5 & 1,500 \\
\hline IEC Extremely Inverse & 2 & 80 & 0,808 \\
\hline
\end{tabular}

\section{METODE PENELITIAN}

Metode penelitian yang dilakuakan diantaranya: studi literatur, observasi, analisa data. Berikut flowchart tugas akhir ini dengan menggunakan ETAP 12.6 , dimana proses sebagai berikut : 


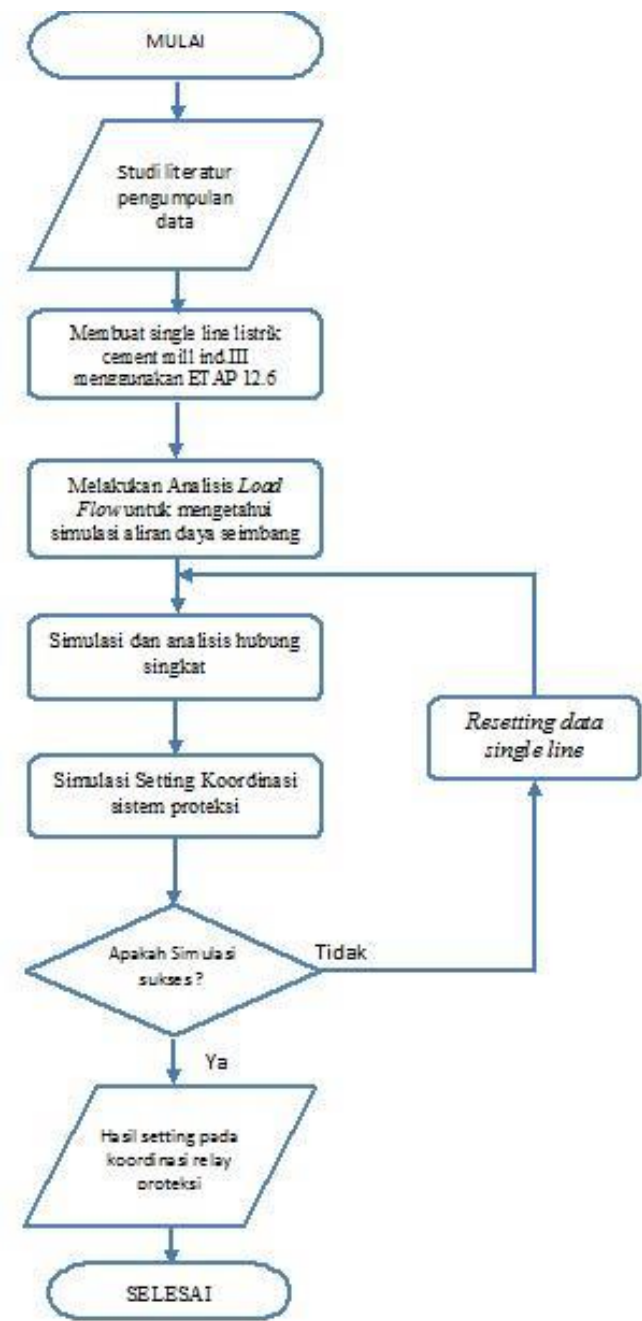

Gbr 3. Flowchart.

\section{HASIL DAN PEMBAHASAN}

Pemodelan Sistem kelistrikan pada Pabrik Cement Mill Indarung III PT. Semen Padang dilakukan dengan cara membuat single line diagram pada software ETAP 12.6. Sebelum melakukan pembuatan single line diagram tersebut maka dilakukan pengumpulan data data yang meliputi data spesifikasi transformator, suplai daya, motor, bus, reley eksisting dan sistem pentanahan. Dari pembuatan single line diagram tersebut maka penulis dapat mengetahui sistem kelistrikan yang digunakan pada pabrik Cement Mill Indarung III PT.Semen Padang . Tahap selanjutnya setelah pemodelan sistem selesai adalah melakukan analisis aliran daya (load flow) untuk mengetahui kondisi sistem pada saat steady state. Dari analisis ini dapat diketahui tegangan bus, beban transformator, beban bus-bar, rugi-rugi daya listrik, faktor daya tiap feeder dan aliran daya.[8]

1. Aliran Daya (Load Flow)
Pendistribusian daya pada Pabrik Cement Mill Indarung III PT. Semen Padang secara keseluruhan disimulasikan dengan menggunakan software ETAP 12.6. Pada tahap awal pensimulasian, dilakukan penginputkan data-data beban, kapasitas trafo dan kapasitas motor sebagai berikut:

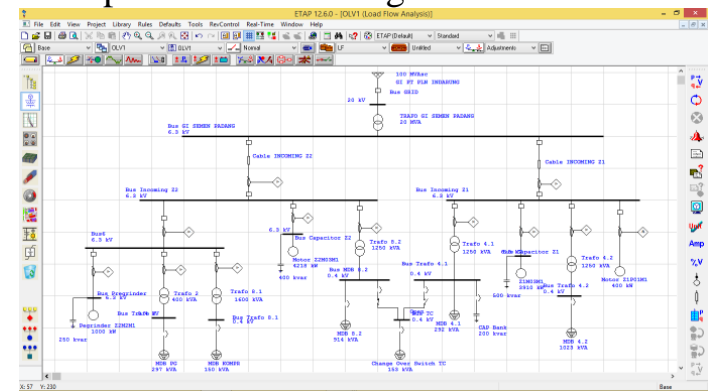

Gbr 4. SLD cement mill indarung III.

3.2 Hasil Running Short Circuit ETAP Hasil running short circuit dari rangkaian distribusi Pabrik Cement Mill Indarung III

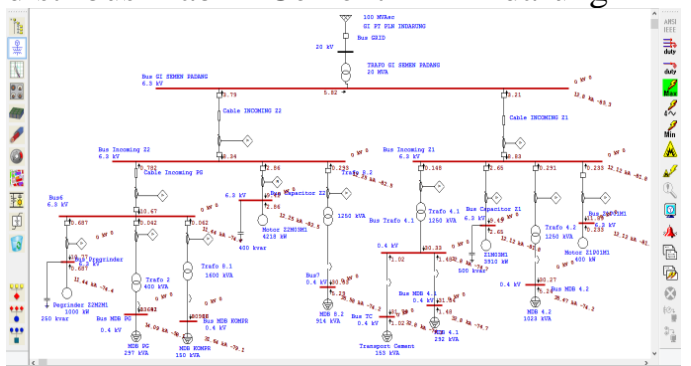

Gbr 5. Running short circuit

Tabel 2 Data hubung singkat maksimum

\begin{tabular}{|c|c|c|c|}
\hline No. & Bus & Tegangan & $\begin{array}{c}\text { Arus Hubung } \\
\text { Singkat } \\
\text { Maksimum }\end{array}$ \\
\hline 1 & MDB PG & $0.4 \mathrm{kV}$ & $14.09 \mathrm{kA}$ \\
\hline 2 & MDB KOMPR & $0.4 \mathrm{kV}$ & $31.64 \mathrm{kA}$ \\
\hline 3 & Bus 6 & $6.3 \mathrm{kV}$ & $11.45 \mathrm{kA}$ \\
\hline 4 & Bus Incoming & $6.3 \mathrm{kV}$ & $12.25 \mathrm{kA}$ \\
\hline 5 & Z2 & $0.4 \mathrm{kV}$ & $36.57 \mathrm{kA}$ \\
\hline 6 & Bus 7 & $0.4 \mathrm{kV}$ & $36.57 \mathrm{kA}$ \\
\hline 7 & Bus TC & $0.4 \mathrm{kV}$ & $36.57 \mathrm{kA}$ \\
\hline 8 & Bus MDB 4.1 & $0.4 \mathrm{kV}$ & $31.81 \mathrm{kA}$ \\
\hline 9 & Bus Trafo 4.1 & $0.4 \mathrm{kV}$ & $31.81 \mathrm{kA}$ \\
\hline 10 & Bus MDB 4.2 & $0.4 \mathrm{kV}$ & $35.46 \mathrm{kA}$ \\
\hline 11 & Bus Incoming & $6.3 \mathrm{kV}$ & $12.12 \mathrm{kA}$ \\
\hline
\end{tabular}

\section{Perhitungan dan analisa Setting OCR}

Koordinasi rele arus lebih gangguan fasa adalah pemilihan pada peralatan pengaman yang bertujuan hanya untuk mengisolasi sistem yang terjadi gangguan arus lebih fasa saja. Gangguannya dapat berupa over load dan short circuit. Sehingga perancangan koordinasi 
proteksi yang baik dan benar akan menjamin keberlangsungan pada proses industri. Pada sistem koordinasi rele pada department Cement Mill Indarung III PT. Semen Padang ini dilakukan pengaturan setting arus dan waktu pada rele arus lebih (50/51). Dari hasil koordinasi tidak diharapkan adanya beberapa peralatan pengaman yang bekerja bersamaan. Pada perhitungan setting rele arus lebih ini akan dihitung nilai low set, high set, dan time dial. Setelah mendapatan perhitungan pada parameter parameter yang telah ditentukan, maka langkah selanjutnya adalah plot Time current curve pada Star Protective Device Coordination yang terdapat pada ETAP sehingga bisa dilihat setting koordinasi yang benar. Koordinasi rele ini harus memperhitungkan rele yang berada diatasnya atau dibawahnya.

\section{Perhitungan Manual dari Relay}

Dalam penelitian ini penulis melakukan 6 skenario percobaan gangguan. Untuk skenario 1 dicantumkan lengkap perhitungan settingan rele dan plot kurva koordinasinya. Sedangkan untuk skenario 2 sampai skenario 6 hasil perhitungannya dapat dilihat pada table IV.2. Ketujuh skenario tersebut adalah: a. Skenario 1 gangguan pada bus lump load MDB PG

b. Skenario 2 gangguan pada bus lump load MDB KOMPR

c. Skenario 3 gangguan pada bus lump load MDB

d. Skenario 4 gangguan pada bus lump loadTransport Cement

e. Skenario 5 gangguan pada bus lump load MDB 4.1

f. Skenario 6 gangguan pada bus lump load MDB 4.2

3.5 Skenario 1 (Gangguan bus lump load MDB PG.

Pada LVCB tidak menggunakan rele, Sedangkan pada HVCB menggunakan rele. LVCB yang dikoordinasikan adalah LVCB PG. Sedangkan rele yang dikoordinasikan adalah rele trafo 2 dan rele incoming $P G$. seperti gambar dibawah.

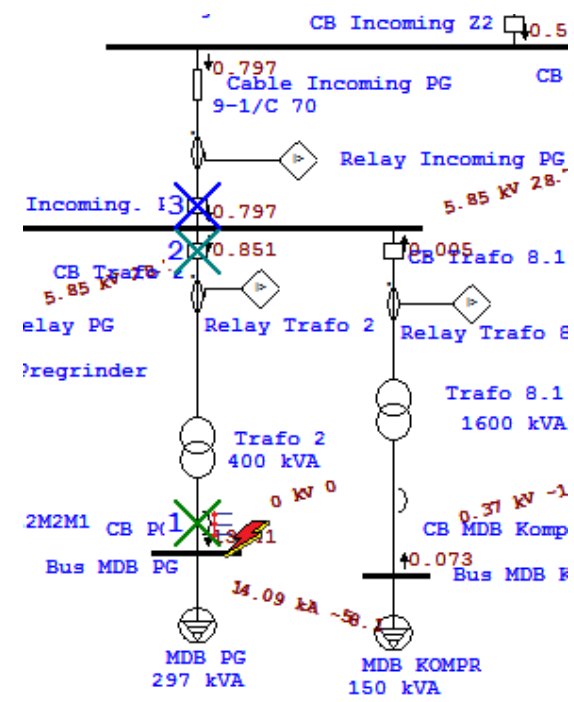

Gbr 6. Koordinasi skenario 1.

a. LVCB Lump Load MDB PG

$I_{n}=425.3$ A (running load flow)

$$
\begin{aligned}
& I_{\text {set }}=I_{n} x 1.1 \\
& =425.3 \times 1.1 \\
& I_{\text {set }}=467.96 \quad(\text { chose }: 468) \\
& \text { Pickup }=\frac{I_{\text {sit }}}{\text { ratio }}=\frac{468}{630}
\end{aligned}
$$$$
=0.73
$$

b. Rele Trafo 2

Data Rele Trafo 2 adalah sebagai berikut:

Manufacture : Merlin Gerin

Model : Sepam 1000+ T40 Curve Type :

Standard Invers

CT Ratio : 75/1

In : $26.9 \mathrm{~A}$

Isc max bus $6: 11.45 \mathrm{kA}(6.3 \mathrm{kV})$

a. Time over current pick-up

$$
\begin{aligned}
I_{s e t} & =I_{n} \times 1.1 \\
& =26.9 \times 1.1 \\
I_{s s t} & =29.59 \text { A (chose: } 29.6)
\end{aligned}
$$

Maka diperoleh nilai pick-up pada rele yaitu:

$$
\begin{aligned}
\text { pickup }=\frac{l_{\text {sat }}}{C T_{p}} & =\frac{29.6}{75} \\
& =0.394(\text { chose: } 0.4)
\end{aligned}
$$

Time dial Dipilih waktu operasi $=0.1 \mathrm{~s}$ 


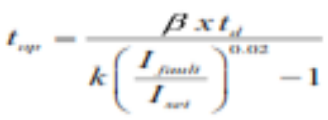

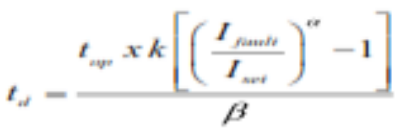

$$
\begin{aligned}
& t_{d}-\frac{0.1 \times 2.97\left[\left(\frac{11450}{29.6}\right)^{0.02}-1\right]}{0.14} \\
& t_{d}=\frac{0.297[0.12]}{0.14} \\
& t_{d}-0.25
\end{aligned}
$$

c. Rele Incoming PG

Data Rele Incoming PG adalah sebagai berikut:

Manufacture : Merlin Gerin

Model : Sepam 1000

Curve Type : Standard Invers

CT Ratio : 200/5

In $: 139.6$

Isc Incoming PG : $12.25 \mathrm{kA}(6.3 \mathrm{kV})$

Time over current pick-up

$$
\begin{aligned}
I_{\text {set }} & =I_{n} \times 1.1 \\
& =139.6 \times 1.1 \\
I_{\text {set }} & =153.56 \mathrm{~A}
\end{aligned}
$$

Maka diperoleh nilai pick-up pada rele yaitu:

$$
\text { pickup }=\frac{l_{\text {sat }}}{C T_{D}}=\frac{153.56}{200}=0.76
$$

- Time dial.

Dipilih waktu operasi adalah $=0.4 \mathrm{~s}$

$$
\begin{gathered}
t_{\text {op }}=\frac{\beta x t_{d}}{k\left(\frac{I_{\text {funt }}}{I_{\text {set }}}\right)^{0.02}-1} \\
t_{d}=\frac{t_{\text {cop }} x k\left[\left(\frac{I_{\text {sanut }}}{I_{\text {set }}}\right)^{\alpha}-1\right]}{\beta} \\
t_{d}=\frac{0.4 x 2.97\left[\left(\frac{12250}{153.56}\right)^{0.02}-1\right]}{0.14} \\
t_{d}=\frac{1.18[1.091-1]}{0.14} \\
t_{d}=\frac{1.18[0.091]}{0.14} \\
t_{d}=0.76
\end{gathered}
$$

Hasil simulasi dan analisa kurva

Dengan menggunakan hasil perhitungan diatas, maka dapat di plot menggunakan Time current curve pada Star-Protective Device Coordination yang terdapat pada ETAP12.6. Dan hasilnya adalah seperti gambar berikut:

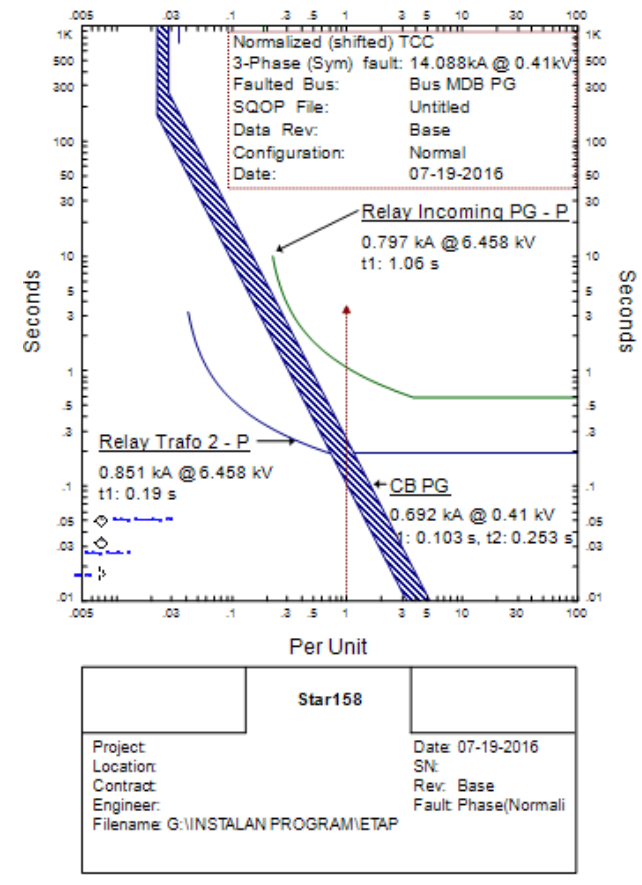

Gbr. 7 Kurva koordinasi skenario 1

Pada Gambar 7 diatas, dapat diketahui bahwa arus gangguan (If) yang terjadi pada jaringan adalah 0,692 kA. Koordinasi rele Trafo 2 dan rele incoming PG dalam keadaan baik karena waktu rele Trafo 2 mentripkan LVCB Trafo 2 lebih cepat dibandingkan LVCB Incoming PG (rele incoming PG) saat terjadi gangguan berada di ujung jaringan, maka waktu trip LVCB Trafo 2 yaitu 0,19 detik sedangkan waktu trip Incoming PG yaitu 1,06 detik.

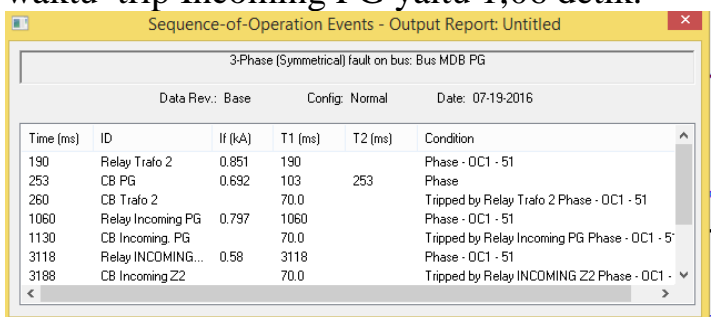

Gbr. 8 Output Report skenario 1.

Sesuai hasil plot dapat disimpulkan sebagai berikut:

LVCB PG berfungsi sebagai pelindung beban lamp load MDB PG dari kondisi arus lebih beban penuh (overload) maupun pada saat starting motor. Selain itu LVCB ini berfungsi juga untuk mengamankan arus lebih hubung singkat yang terjadi pada motor. $\square$ Rele Trafo 2 berfungsi sebagai pelindung trafo 2 terhadap 
arus lebih beban penuh dan arus lebih hubung singkat yang terjadi pada bus 6 . Selain itu rele ini juga berfungsi sebagai backup LVCB PG apabila gagal bekerja.

\section{Skenario 2 (Gangguan MDB KOMP)}

Pada Gambar dibawah ini adalah gambar scenario 2 yang terdiri LVCB MDB KOMPR, rele trafo 8.1 dan rele incoming PG. Pada running ETAP 12.6, diberi gangguan pada bus MDB KOMPR maka CB MDB KOMPR akan trip terlebih dahulu. Jika CB MDB KOMPR gagal dalam memproteksi maka CB Trafo 8.1 akan trip. Jika CB Trafo 8.1 masih gagal dalam memproteksi maka CB Incoming PG akan trip. Hal ini dapat dilihat pada gambar berikut:

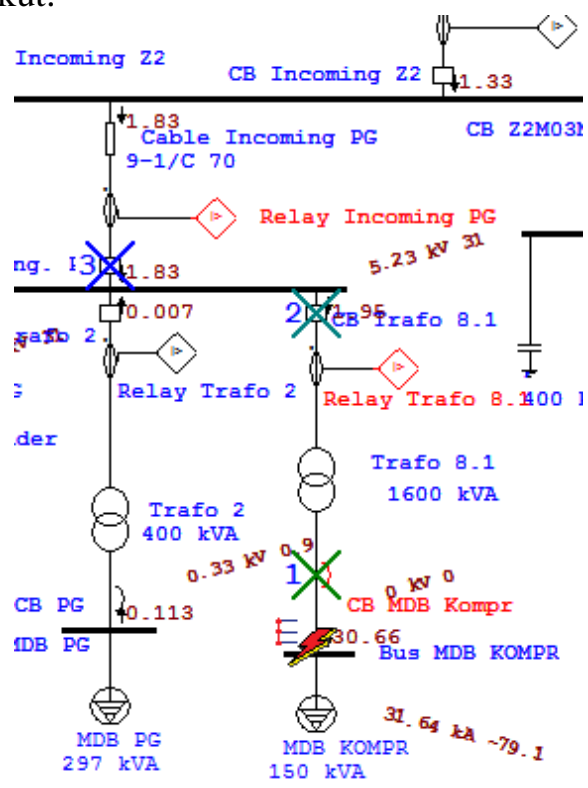

Gbr 9. Tipikal skenario 2.

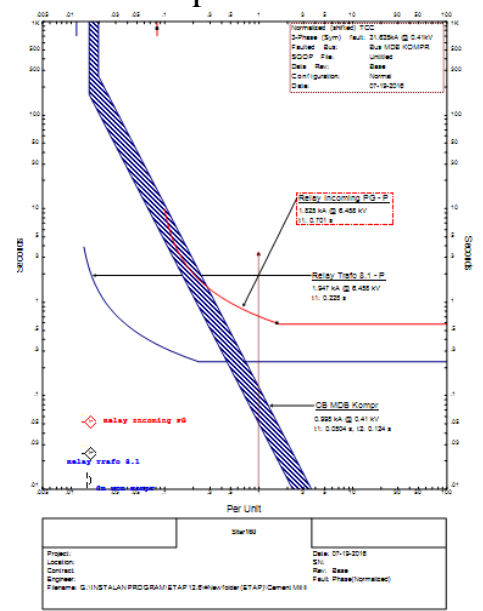

Gbr 10. Kurva koordinasi skenario 2.

Pada Gambar 10 diatas, dapat diketahui bahwa arus gangguan (If) yang terjadi pada jaringan adalah 0,998 kA. Koordinasi rele Trafo 8.1 dan rele incoming PG dalam keadaan baik karena waktu rele Trafo 8.1 mentripkan LVCB Trafo 8.1 lebih cepat dibandingkan LVCB Incoming PG (rele incoming PG) saat terjadi gangguan berada di ujung jaringan, maka waktu trip LVCB Trafo 8.1 yaitu 0,228 detik sedangkan waktu trip Incoming PG yaitu 0,701 detik

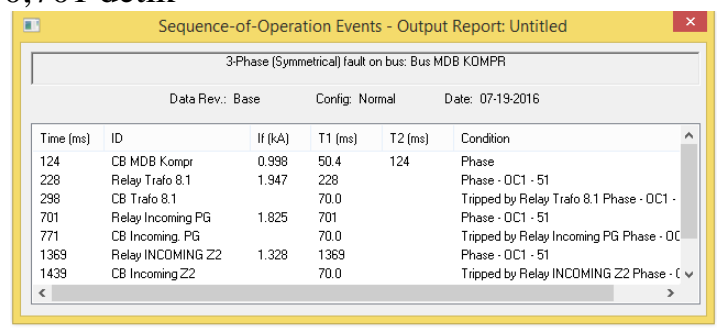

Gbr 11. Output Report skenario 2

\section{Skenario 3 (Gangguan pada MDB 8.2)}

Pada Gambar dibawah ini adalah gambar scenario 3 yang terdiri LVCB MDB 8.2, rele trafo 8.2 dan rele incoming $\mathrm{Z} 2$. Pada running ETAP 12.6, diberi gangguan pada bus 7 yaitu bus MDB 8.2maka CB MDB 8.2 akan trip terlebih dahulu. Jika CB MDB 8.2 gagal dalam memproteksi maka $\mathrm{CB}$ Trafo 8.2 akan trip. Jika CB Trafo 8.2 masih gagal dalam memproteksi maka CB Incoming Z2 akan trip. Hal ini dapat dilihat pada gambar berikut:

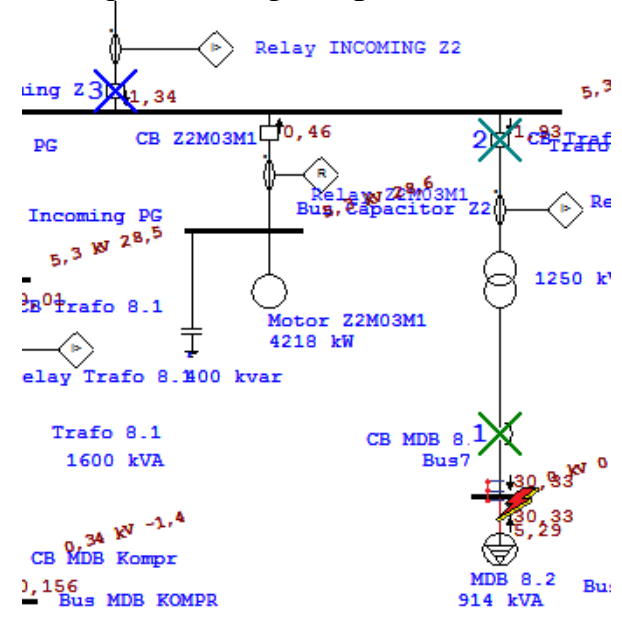

Gbr. 12. Tipikal koordinasi skenario 3. 


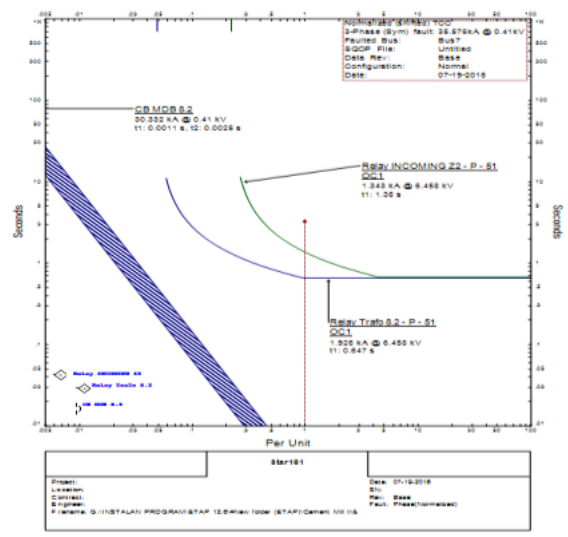

Gbr 13. Kurva koordinasi skenario 3.

Keterangan: Pada Gambar 15 diatas, dapat diketahui bahwa arus gangguan (If) yang terjadi pada jaringan adalah 30,332 kA. Koordinasi rele Trafo 8.2 dan rele incoming Z2 dalam keadaan baik karena waktu rele Trafo 8.2 mentripkan LVCB Trafo 8.2 lebih cepat dibandingkan LVCB Incoming Z2 saat terjadi gangguan berada di ujung jaringan, maka waktu trip LVCB Trafo 8.2 yaitu 0,647 detik sedangkan waktu trip Incoming $\mathrm{Z} 2$ yaitu 1,36 detik.

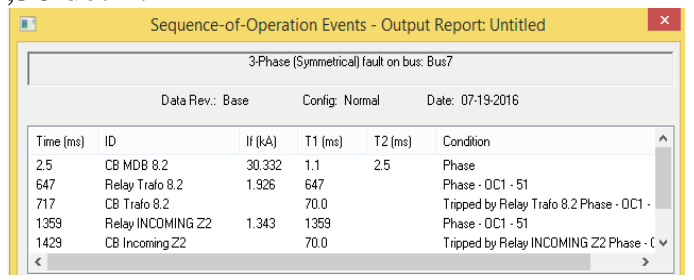

Gbr 14. Output Report skenario 3

3.8 Skenario 4 (Gangguan pada bus lump load TC).

Pada Gambar dibawah ini adalah gambar scenario 4 yang terdiri LVCB TC, rele trafo 4.1, dan rele incoming $\mathrm{Z} 1$. Pada running ETAP 12.6, diberi gangguan pada bus TC saat Disuplai dari Z1. maka CB TC akan trip terlebih dahulu. Jika $\mathrm{CB}$ TC gagal dalam memproteksi maka CB 21 akan trip. Jika CB 21 masih gagal dalam memproteksi maka $\mathrm{CB}$ Trafo 4.1akan trip. Hal ini dapat dilihat pada gambar berikut:

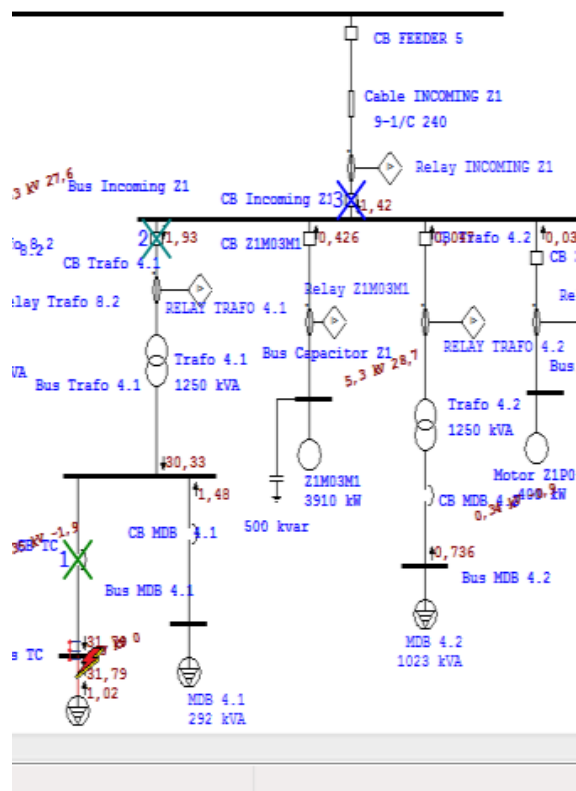

$\overline{\text { Gbr } 15 \text { Tipikal koordinasi skenario } 4}$.

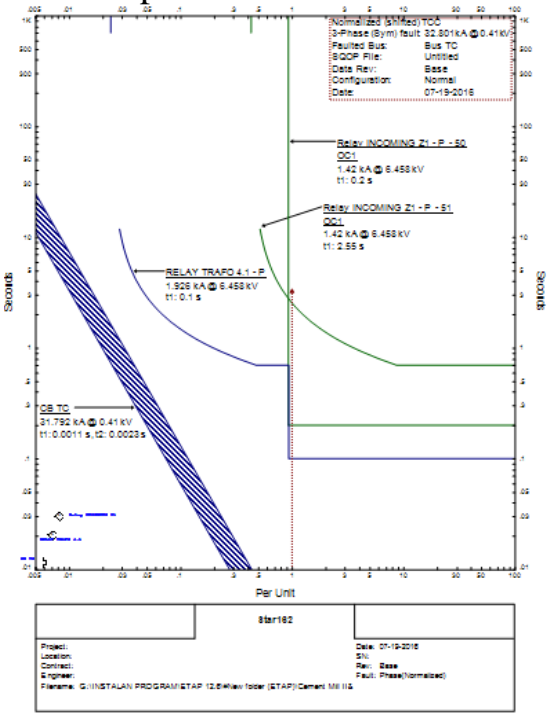

Gbr 16. Kurva koordinasi skenario 4

Keterangan: Pada Gambar IV.19 diatas, dapat diketahui bahwa arus gangguan (If) yang terjadi pada jaringan adalah 31,792 kA. Koordinasi rele Trafo 4.1 dan rele incoming Z1 dalam keadaan baik karena waktu rele Trafo 4.1 mentripkan LVCB Trafo 4.1 lebih cepat dibandingkan LVCB Incoming Z1 saat terjadi gangguan berada di ujung jaringan, maka waktu trip LVCB Trafo 4.1 yaitu 0,1 detik sedangkan waktu trip Incoming $\mathrm{Z} 1$ yaitu 2,55 detik.

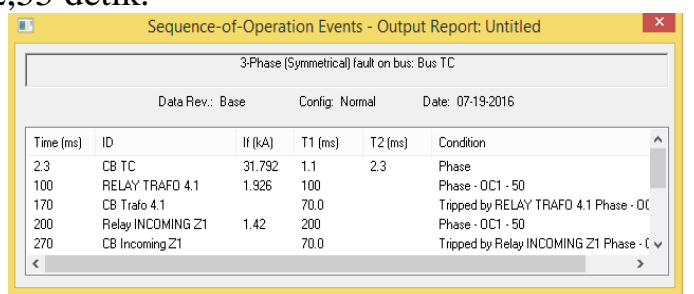

Gbr 17. Output Report skenario 4 


\section{Skenario 5 (Gangguan pada MDB 4.1)}

Pada Gambar dibawah ini adalah gambar scenario 5 yang terdiri LVCB MDB 4.1, rele trafo 4.1 dan releIncoming $\mathrm{Z} 1$. Pada running ETAP 12.6, diberi gangguan pada bus MDB 4.1, maka CB1yaitu CB MDB 4.1 akan trip terlebih dahulu. Jika CB MDB 4.1 gagal dalam memproteksi maka CB Trafo 4.1 akan trip. Jika CB Trafo 4.1 masihgagal dalam memproteksi maka CB Incoming Z1 akan trip. Hal ini dapat dilihat pada gambar berikut:

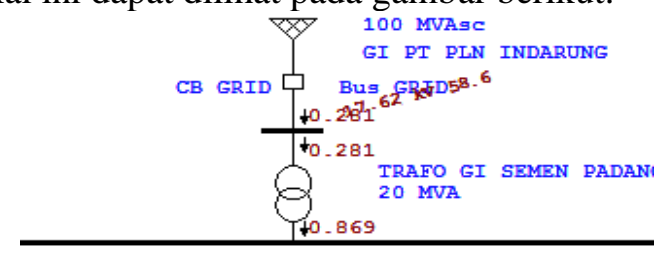

22

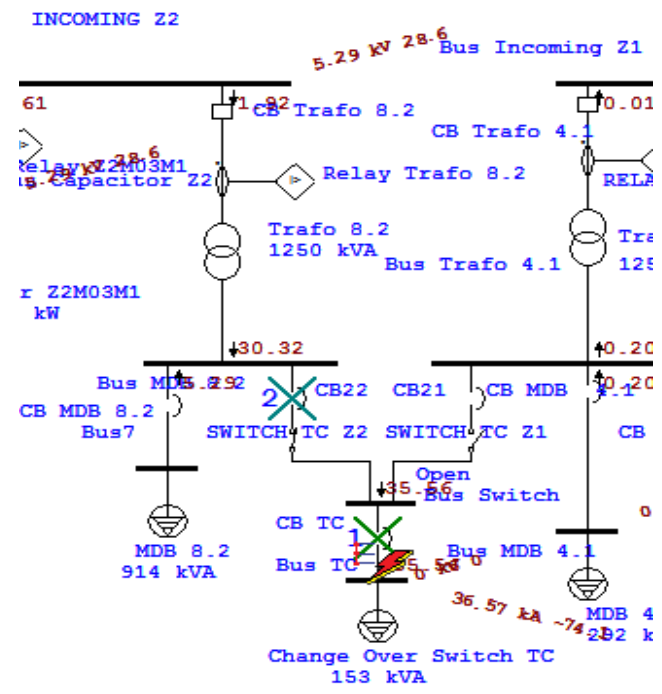

Gbr 18. Tipikal koordinasi skenario 5

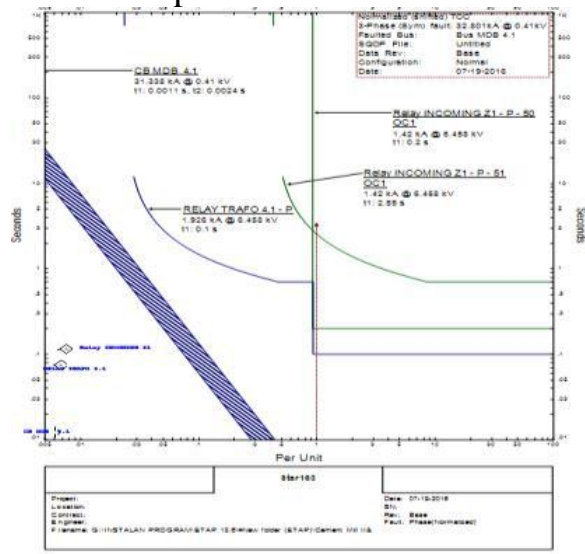

Gbr. 19 Kurva koordinasi skenario 5

Keterangan: Pada Gambar IV.23 diatas, dapat diketahui bahwa arus gangguan (If) yang terjadi pada jaringan adalah 31,792 kA. Koordinasi rele Trafo 4.1 dan rele incoming
Z1 dalam keadaan baik karena waktu rele Trafo 4.1 mentripkan LVCB Trafo 4.1 lebih cepat dibandingkan LVCB Incoming Z1 saat terjadi gangguan berada di ujung jaringan, maka waktu trip LVCB Trafo 4.1 yaitu 0,1 detik sedangkan waktu trip Incoming Z1 yaitu 2,55 detik.

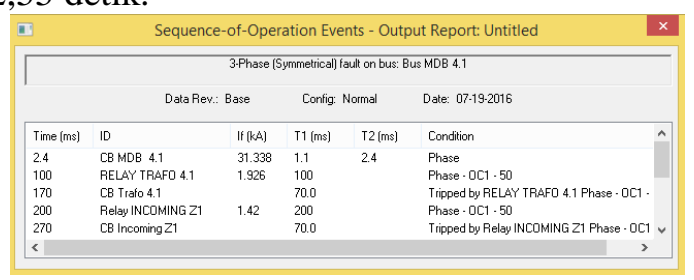

Gbr 20. Output Report skenario 5

\section{Skenario 6 (Gangguan pada MDB 4.2)}

Pada Gambar dibawah ini adalah gambar skenario 6 yang terdiri LVCB MDB 4.2, rele trafo 4.2 dan rele Incoming Z1. Pada running ETAP 12.6, diberi gangguan pada bus MDB 4.2, maka CB MDB 4.2 akan trip terlebih dahulu. Jika CB MDB 4.2 gagal dalam memproteksi maka CB Trafo 4.2 akan trip. Jika CB Trafo 4.2 masih gagal dalam memproteksi maka CB Incoming Z1 akan trip. Hal ini dapat dilihat pada gambar berikut:

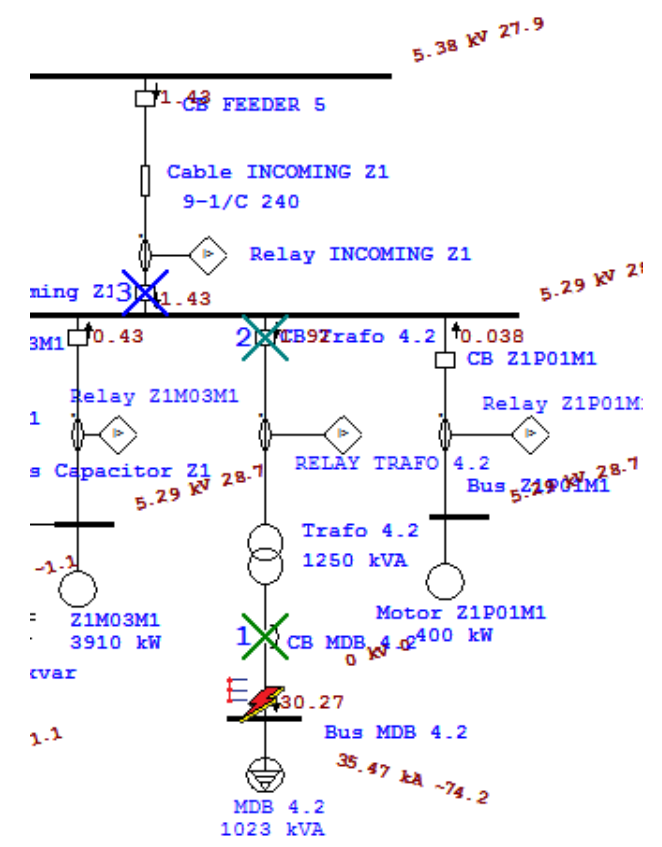

Gbr 21. Tipikal koordinasi skenario 6 


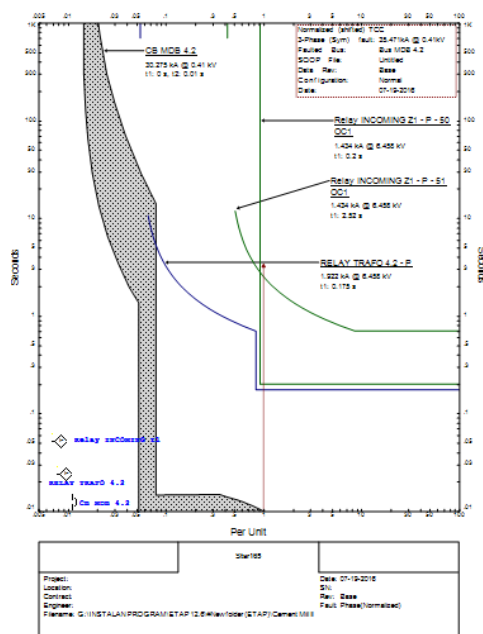

Gbr, 22. Kurva koordinasi skenario 6

Keterangan: Pada Gambar IV.15 diatas, dapat diketahui bahwa arus gangguan (If) yang terjadi pada jaringan adalah $30,275 \mathrm{kA}$. Koordinasi rele Trafo 4.2 dan rele incoming Z1 dalam keadaan baik karena waktu rele Trafo 4.2 mentripkan LVCB Trafo 4.1 lebih cepat dibandingkan LVCB Incoming Z1 saat terjadi gangguan berada di ujung jaringan, maka waktu trip LVCB Trafo 4.2 yaitu 0,175 detik sedangkan waktu trip Incoming Z1 yaitu 0,2 detik.

\begin{tabular}{|c|c|c|c|c|c|}
\hline No & Rele / LVCB & $\begin{array}{l}\text { I set } \\
\text { (A) }\end{array}$ & $\begin{array}{l}\text { Pickup } \\
\text { (s) }\end{array}$ & $\begin{array}{l}\text { Top } \\
\text { (s) }\end{array}$ & Td \\
\hline \multirow{3}{*}{1} & LVCB MDB PG & 466 & 0.73 & & \\
\hline & Rele Trafo 2 & 29.6 & 0.4 & 0.1 & 0.25 \\
\hline & Rele Incoming PG & 153.34 & 0.76 & 0.4 & 0.76 \\
\hline \multirow{3}{*}{2} & $\begin{array}{l}\text { LVCB MDB } \\
\text { KOMPR }\end{array}$ & 242.66 & 0.48 & & \\
\hline & Rele Trafo 8.1 & 15.4 & 0.3 & 0.1 & 0.3 \\
\hline & Rele Incoming PG & 153.34 & 0.76 & 0.4 & 0.76 \\
\hline \multirow{3}{*}{3} & LVCB MDB 8.2 & 1497.8 & 0.75 & & \\
\hline & Rele Trafo 8.2 & 95 & 0.79 & 0.4 & 0.85 \\
\hline & Rele Incoming Z2 & 722.26 & 0.60 & 0.7 & 0.88 \\
\hline \multirow{3}{*}{4} & LVCB TC & 249.26 & 0.50 & & \\
\hline & Rele Trafo 4.1 & 45.65 & $\overline{0.38}$ & 0.4 & 0.91 \\
\hline & Rele Incoming Z1 & 631.29 & 0.52 & 0.7 & 0.92 \\
\hline \multirow{3}{*}{5} & LVCB MDB 4.1 & 470 & 0.75 & & \\
\hline & Rele Trafo 4.1 & 45.65 & 0.38 & 0.4 & 0.91 \\
\hline & Rele Incoming $\mathrm{Zl}$ & 631.29 & 0.52 & 0.7 & 0.92 \\
\hline \multirow{3}{*}{6} & LVCB MDB 4.2 & 1664.85 & 0.83 & & \\
\hline & Rele Trafo 4.2 & 105.71 & 0.88 & 0.4 & 0.83 \\
\hline & Rele Incoming Z1 & 631.29 & 0.52 & 0.7 & 0.92 \\
\hline
\end{tabular}

\section{SIMPULAN DAN SARAN}

Kesimpulan Berdasarkan hasil running koordinasi OCR untuk Pabrik Cement Mill Indarung III PT. Semen Padang menggunakan ETAP 12.6, maka dapat diambil beberapa kesimpulan sebagai berikut:

1. Hasil simulasi menunjukkan bahwa rele sudah bekerja secara Over lappings Sehingga dapat saling backup. Hal tersebut terlihat dari hasil running simulasi dimana rele dapat men- trip-kan secara berurutan dari yang paling dekat kesumber gangguan.

2. Dari 6 buah scenario gangguan yang dilakukan, terdapat koordinasi rele OCR yang baik dan kurang baik yang terbawah .Koordinasi terbaik adalah koordinas irele OCR pada scenario keenam yaitu gangguan pada bus MDB 4.2 .Rele OCR yang dikoordinasikan adalah rele trafo 4.2 dengan rele Incoming Z1, dimana perbedan nilai Time Dial-nya adalah 0.09 dengan perbedaan waktu trip CB rele trafo 4.2 dengan CB rele incoming $\mathrm{Z} 1$ adalah $25 \mathrm{~ms}$. Sedangkan urutan koordinasi terbawah adalah koordinasi pada scenario pertama.

\section{DAFTAR PUSTAKA}

1. Hirlanda, Dwi Andikta. 2013. Simulasi dan Analisis Koordinasi Proteksi pada PT. Pertamina RU IV Cilacap. Institut Teknologi sepuluh November, Surabaya.

2. Kasmir.Koordinasi Rele Arus Lebih di Gardu Induk Bukit Siguntang Dengan Simulasi (Etap 6.00) .. Politeknik Negeri Sriwijaya, Palembang.

3. Madrensyah, Adrial.2008. Studi Perencanaan Koordinasi Rele Proteksi pada Saluran Udara Tegangan Tinggi Gardu Induk Gambir Lama - Pulomas . Universitas Indonesia, Depok

4. Nindia, Afma. 2014. Studi Perancangan Koordinasi Rele Proteksi Untuk Sistem Kelistrikan Pabrik Indarung VI Pt Semen Padang. Jurusan Teknik Elektro. Universitas Andalas, Padang.

5. Sanzarian, Yogi.2015. Koordinasi Rele Arus Lebih dan Rele Gangguan Tanah Menggunakan Program Berbasis Electric Transient and Analysis Program (Etap) Pada Gardu Induk Bungarandi PT. PLN (Persero) UPT Palembang. Politeknik Negeri Sriwijaya, Palembang.

6. Sastrawan. 2010. Analisa Setting Rele OCR (Over Current Relay) pada Sistem $150 \mathrm{kV}$ Bali Pasca Dioperasikannya Pembangkit Celukan Bawang. Universitas Udayana Bali.

7. Yanuwirawan, Edo, Margo Pujiantara dan R. Wahyudi. 2015."Studi Koordinasi Proteksi Rele Arus Lebih dan Ground Fault Pada Sistem Eksisting PT. VICO Indonesia, Kalimantan Timur"dalam Jurnal Teknik ITS Vol. 4, No. 2,Institut Teknologi Sepuluh Nopember, Surabaya 
8. Zulkarnaini, Eko Saputra H. 2012."Evaluasi Koordinasi Relay Proteksi Pada Feeder Distribusi Tenaga Listrik (Gh Tanjung Ampalu Sijunjung.) Jurnal Teknik Elektro Institut Teknologi Padang.Padang 